\title{
DEVELOPING A FRAMEWORK FOR UNDERSTANDING THE PERSONAL MOTIVATIONS OF SUSTAINABILITY LEADERS
}

JENNIFER LICAD HORN (corresponding author)

Department of Leadership \& Strategy

John Gokongwei School of Management

Ateneo de Manila University, Quezon City, Philippines

jhorn@ateneo.edu

WALTER WEHRMEYER

Centre for Environment and Sustainability

University of Surrey, U.K.

w.wehrmeyer@surrey.ac.uk

\begin{abstract}
This study explores the initial and sustaining motivations that drive leaders to pursue sustainability as a profession or vocation. Exploratory interviews were conducted with 16 sustainability leaders in the Philippines working in sectors ranging from corporate to social enterprise, NGO, and academia. Findings from thematic analysis reveal significant life experiences that drive initial motivation, how feedback sustains motivation, and the importance of self-awareness and positive psychological factors in starting and sustaining their work or advocacy. A framework for understanding motivations is developed therein, drawing on themes extracted from the interviews, Stern's Value-Belief-Norm Theory, and Authentic and Transformational Leadership theories. Recommendations are given on how motivation can be instigated and sustained, namely, by cultivating hope and other positive psychological factors, integrating experiential learning to develop awareness, connectedness, and empathy, and creating social support and enabling environments. Further research to develop an instrument for measuring sustainability leadership motivation, one that can inform sustainability education facilitators of the effectiveness of their programs in inspiring participants to take action, is also recommended.
\end{abstract}

\section{KEYWORDS}

sustainability; leadership; motivation; hope 


\section{INTRODUCTION}

Haney et al. (2018) state that sustainability leadership development needs not only new knowledge and skills but an underlying motivation to act so knowledge and skills are utilized. Studies have been done on the values and attributes (Goleman, Boyatzis, \& McKee, 2002; Goleman, 2004; Parkin, 2010; Schein, 2015), life experiences (Rimanoczy, 2013; Schein, 2015), and pedagogical practices (Burns, Diamond-Vaught, \& Bauman, 2015; Haney, Pope, \& Arden, 2018) that encourage the development of sustainability leaders. Studies on sustainability leadership and motivation, however, are sparse, and the few that exist particularly on the motivations of sustainability leaders have been limited to a developed world context and to corporate sustainability executives.

This study, therefore, hopes to add perspectives from other sectors and from a developing world context by asking, "What are the initial and sustaining motivations of individual sustainability leaders (whether in business, government, NGOs, or civil society) in a developing country like the Philippines?"

\section{UNDERSTANDING MOTIVATION}

\section{Motivation and Leadership}

Though some leadership theories describe the characteristics, skills, and behaviors of particular leader types that are suitable for sustainability, the motivations of these types of leaders are hardly discussed. Authentic Leadership, however, discusses the role of positive psychological factors and critical life events in the formation of sustainability leaders while Transformational Leadership discusses change or transformation as the goal of the leader. Both frameworks as such indicate possible motivations for leader emergence.

Environmentally-specific transformational leaders, such as Patagonia's Yvon Chouinard (Chouinard, 2006), Interface's Ray Anderson (Rimanoczy, 2013), The Body Shop's Anita Roddick (Pless, 2007), or primatologist Jane Goodall (Gerber, 2017), convey visions of the future to their team, explain how to make these a reality, exhibit optimism, and act as role models by openly discussing values and issues and taking actions in line with their values (Graves \& Sarkis, 2018; Robertson \& Barling, 2013, 2017). 
Authentic leadership focuses on leading with authenticity and trustworthiness, particularly in times of social upheaval, environmental crisis, or situations that create fear and uncertainty (Avolio \& Gardner, 2005). Walumbwa et al. (2008) conceptualize authentic leadership with positive psychological factors of confidence, hope, optimism, and resilience. These factors, combined with critical life eventswhether these be negative or positive-and the meanings that leaders attach to them, shape them to lead with their values (Northouse, 2016; Shamir \& Eilam, 2005). This echoes the transformative effect of some life experiences of corporate leaders in the Rogers (2012), Rimanoczy (2013), and Schein (2015) studies discussed in the following section.

\section{Motivations of Sustainability Leaders}

In one study on the worldviews of executives and their ability to confront global environmental challenges, Rogers (2012) found that they identified specific moments that caused shifts in how they thought about the environment. These were sometimes described as epiphanies while others experienced more gradual shifts as they grew older.

In Rimanoczy's (2013) study on corporate leaders, the range of moments or experiences discussed came from their early childhood role models or upbringing as well as from their epiphanies as adults. This aligns with studies wherein learning and behavior are correlated with the observation of models, whether these be individuals in real life or in media (Bandura, 1977). Rimanoczy's study also revealed how transformational encounters with nature contributed to these leaders' connectedness with the environment.

Building on Rimanoczy's work, Schein's (2015) study focused on the development of corporate sustainability leaders' ecological worldview or their beliefs about their relationship with the environment. He states that ecological worldviews can enhance the perception of interdependence with the ecosystem, which can strengthen one's commitment to sustainability despite resistance to changes in the status quo. Schein found five key life experiences that shape the ecological worldviews and motivations of senior sustainability executives at multinational companies, namely, family origin and early childhood experiences in nature; environmental education and memorable teachers and mentors; seeing environmental degradation in developing countries; 
perceiving capitalism as a vehicle for environmental or social activism; and having a sense of spirituality and service.

These studies indicate how the insight gained from life experiences in both childhood and adulthood created an impetus for leaders to take action toward sustainability. They also highlight the importance of ethical values and a desire to change the status quo (as mentioned in transformational leadership) as well as of critical life events (as discussed in authentic leadership). The following section as such links these with values, beliefs, and norms that help drive leaders to behave sustainably, influence others, and, ultimately, to contribute to social or environmental transformation.

\section{Theoretical Framework on Motivating Sustainable Behavior}

Research citing leaders' values (Parkin, 2010; Schein, 2015) suggests that because sustainability leaders challenge the status quo, they will not necessarily be motivated by prevailing social norms. The Value-Belief-Norm Theory or VBN (Figure 1; see Stern, Dietz, Abel, Guagnano, \& Kalof, 1999; Stern, 2000) proposes that sustainable behaviors follow when one's personal norms-feelings of moral obligation to perform or refrain from specific actions-are activated by an awareness of consequences. Such an awareness is affected by one's ecological worldview which, in turn, is influenced by one's values (i.e., guiding principles in one's life; see Schwartz, 1992, 1994).

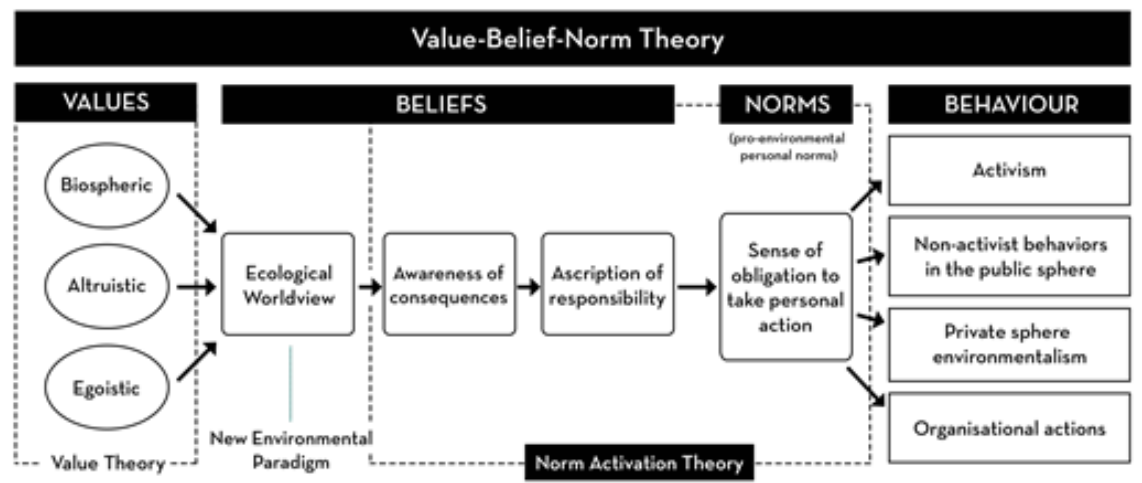

Figure 1: The Value-Belief-Norm Theory (Stern, 2000) 
The Value-Belief-Norm Theory also cites three main values: 1) biospheric and 2) altruistic values (both of which are considered self-transcendent), which tend to be more positively related to sustainable behavior, and 3) egoistic (or self-enhancement) values, which are more negatively related to sustainable behavior. People will be more motivated in general to act upon their self-transcendent values when these are activated in a specific context, linked to their self-concept, and supported by cognitive reasons (Steg, van den Berg, \& de Groot, 2013). In other words, most people would be more motivated by internalized or self-determined reasons for engaging in sustainable action. Leaders, therefore, need more self-determined motivations to engage consistently in sustainable behavior in the face of challenges across different contexts (Bamberg, Hunecke, \& Blöbaum, 2007; Dovidio, Piliavin, Schroeder, \& Penner, 2006; Hunecke, Blöbaum, Matthies, \& Höger, 2001; Ryan \& Deci, 2000; Venhoeven, Bolderdijk, \& Steg, 2016).

\section{SIGNIFICANCE OF THE STUDY}

By developing a framework based on existing literature and newly gathered data, sustainability leadership programs can be improved particularly when they integrate ways to develop motivation alongside technical knowledge and skills. Exploring the initial motivations of sustainability leaders can also help inform how to influence sustainability advocates to take on more significant leadership roles in their community or organization, while looking into sustaining motivations can aid in keeping sustainability leaders doing the necessary work despite bleak outlooks or challenges that come their way.

\section{METHODOLOGY}

Given the lack of research on individual motivations of sustainability leaders, particularly in the Philippines, an exploratory approach was adopted using qualitative methods. This allowed the researcher to navigate through the individual experiences of sustainability leaders in depth, allowing better understanding and contextualization of the data (Gilbert, 2001; Miles, Huberman, \& Saldaña, 2014; Silverman, 2014). 


\section{Sampling}

Data from specific individuals identified as "sustainability leaders" was gathered using purposive and snowball sampling. A sustainability leader was broadly defined as follows: an individual who has been working in sustainability or sustainable development for at least five years (to ensure that they have committed a meaningful amount of time to working on sustainability while still allowing for the inclusion of younger sustainability leaders in their 20s and 30s); manages a team or collaborates with others, in that a leader is one who leads others; and influences positive change toward sustainability through their projects, products, or programs. An initial form was sent to prospective interviewees to ensure that they met the criteria and to include a diversity of perspectives across sector, industry, age, and gender.

The 16 respondents in the study came from social enterprises, NGOs, corporations, and civil society organizations, with 12 of them hailing from either the social enterprise or NGO sectors. Industries also varied, ranging from manufacturing to agriculture, conservation, and tourism as well as to real estate, research and urban planning, and campaigning and policy. Ages ranged from 26 to 58 with a mean age of $40.57 \%$ were female and $43 \%$ were male. All the respondents had been working in sustainable development for 5 to 35 years, with 16 years as the average, and had considerable influence and decision-making capabilities within their organizations. Ten out of the 16 interviewees were either presidents or executive directors, with seven of them being co-founders of their respective organizations. The remaining six interviewees were directors of sustainability or heads of departments or offices in which they worked.

\section{Research Method}

Data was collected through semi-structured interviews that focused on the main research questions while allowing for flexibility to alter their sequence or probe for more information when appropriate (Silverman, 2014). The use of focus groups was rejected due to logistical reasons and, more importantly, because individuals might modify their responses in the presence of others or feel restricted to speak about personal matters. 
The interview questions were informed by the main research question. In exploring initial motivations, the questions asked included the following: "Why do you do what you do? What motivated you to get into this line of work in the first place?" In exploring sustaining motivations, interviewees were asked to recall their biggest challenges or moments where they were close to giving up. They were then asked how they overcame those challenges, or what they learned from those challenges that made them manage to stay on in doing sustainability work. A total of 16 interviews were scheduled throughout June 2019.

Thematic analysis (Braun \& Clarke, 2006) was the chosen method for understanding the data. The researcher also found it useful in the process to compare resulting themes to concepts present in reviewed literature. Swain (2018) refers to this as hybrid thematic analysis, which allows the researcher to be flexible in using inductive and deductive approaches to data analysis, thereby allowing the data to reveal themes while having theories to help inform such.

\section{KEY FINDINGS}

Themes were clustered into two main groups: initial motivation and sustaining motivation, as seen in Figure 2. Themes could then be further categorized as internal motivations, such as positive psychological factors, self-awareness, or self-interest, and external ones, or those influenced by other people or the environment.

Although both groups share some sub-themes, it was important to distinguish what got the interviewees into sustainability in the first place from what keeps them going. Underlying their overall motivation are positive psychological factors like confidence, hope, optimism, resilience, and a sense of moral obligation. Initial motivations are instigated largely by life experiences; sustained motivation, on the other hand, is fueled by feedback and the overarching goal of social and environmental transformation. The following sections describe this in further detail. 


\section{MOTIVATIONS OF SUSTAINABILITY LEADERS}

\begin{tabular}{|c|c|}
\hline INITIAL MOTIVATIONS & SUSTAINING MOTIVATIONS \\
\hline \multicolumn{2}{|c|}{ SELF } \\
\hline \multicolumn{2}{|c|}{ Positive Psychological Factors (PPFs) } \\
\hline $\begin{array}{l}\text { - Confidence } \\
\text { - Hope } \\
\text { - Optimism }\end{array}$ & $\begin{array}{l}\text { - Confidence } \\
\text { - Hope } \\
\text { - Optimism } \\
\text { - Resilience }\end{array}$ \\
\hline \multicolumn{2}{|c|}{ Self-awareness and self-interest } \\
\hline $\begin{array}{l}\text { - Pursuit of happiness or fulfillment } \\
\text { - Avoidance of negative feelings } \\
\text { or consequences }\end{array}$ & $\begin{array}{l}\text { - Pursuit of happiness or fulfillment } \\
\text { - Avoidance of negative feelings } \\
\text { - Financial security } \\
\text { - Perpetual self-reflection / daily reckoning }\end{array}$ \\
\hline \multicolumn{2}{|c|}{ SOCIAL } \\
\hline $\begin{array}{l}\text { - Social injustice } \\
\text { - Role models }\end{array}$ & $\begin{array}{l}\text { - Beneficiaries } \\
\text { - Team / colleagues } \\
\text { - Collaborative community } \\
\text { - Future generations }\end{array}$ \\
\hline
\end{tabular}

\section{ENVIRONMENTAL}

- Connectedness with nature

- Man-made impacts on the environment
- Connectedness with nature

- Growing opportunities in sustainability

SOCIAL AND ENVIRONMENTAL TRANSFORMATION

Figure 2: Motivations of Sustainability Leaders

Initial Motivation

A common theme that emerged was the respondents' personal insights from exposure to the consequences of unsustainable behavior or the positive feelings and opportunities associated with sustainable behavior. These consequences are related to social injustice (e.g., poverty, violations of indigenous peoples' rights, victims of calamities, etc.) or the destruction of nature (e.g., trash along the coast, growing landfills, flooding, etc.) while the positive feelings could be connected with people, such as role models (whether individual persons or organizations), or nature-spending time outdoors or with wildlife, or learning about the natural world through school or media (e.g., reading a perspective-shifting book or watching 
a moving documentary, enlightening travel experiences, etc.). Four main clusters of initial motivations came from positive psychological factors, self-awareness and self-interest, exposure to other people, and exposure to the environment.

Positive psychological factors. Confidence, hope, optimism, and resilience gave the interviewees belief in their personal capacity to effect positive outcomes. They spoke repeatedly in ways that validated their possession of self-efficacy, or confidence in their ability to accomplish a specific task (Northouse, 2016). For example, they would express frustration with the government, other businesses, or other citizens and feel like they were capable to work more effectively toward a solution. They also frequently said that stubborn hope or optimism helped them believe that something could be done about the problem, and that it was within their power to create change, as one social entrepreneur stated:

If each Filipino would invest their time in actually helping somebody else, instead of just blaming somebody, doing instead of just talking, then maybe the world would be a better place.

Self-awareness and self-interest. This also played a role in the interviewees' decision to pursue their path. In some cases, it indulged them in the pursuit of happiness and fulfillment (something they love or are good at). One NGO executive director talked about his desire to continue experiencing the pleasurable things in life as one of his motivations:

Sometimes I think it's also hedonistic.... What are the pleasurable things? Pleasurable things are snorkeling, watching the fish, breathing fresh air. It could also be self-serving, you know?... Fun for me is really enjoying the earth, but not destroying it.

Conversely, they could also act in their self-interest through the desire to avoid negative feelings or consequences. This involves feelings of moral obligation or guilt, the desire to follow their personal norms, or acting in "enlightened self-interest." One entrepreneur shared:

We want to have a sustainable relationship with our customers because if we gave them food contaminated with chemicals, eventually they will get sick and die.... With our farmers, we didn't want to pay them unfairly, because if we don't provide a fair price to them, tomorrow, they will run out of business, and you will lose your supply.... And it's also the same with your environment. If you pollute the environment now, later on, you won't have anywhere to plant. It's better to use it sustainably. 
Several respondents also mentioned their religious belief as a contributing factor in seeing themselves as stewards of the planet and thus in pursuing their spiritual mission. This sense of moral obligation was present not only among those who professed to be Roman Catholic but also in those with other religious beliefs (e.g., Buddhism); indeed, it was also present in those who claimed not to be religious at all.

Social exposure. Exposure to other people in both positive and negative situations also served to influence the interviewees' motivation. They often reported being motivated by seeing social injustice first rather than something linked directly to the environment. One environmental lawyer shared:

I started as a human rights advocate and lawyer, especially defending IPS (indigenous peoples) from incursions [into] their territory, and discovered that environmental law was the best defense for IPs when companies and the government try to dispute on their land.... You can use all of that to make the case that IPs should be left alone or that a project shouldn't be done in their territory.

Indeed, Schein's (2015) study also found that corporate sustainability executives often reported that their exposure to poverty, inequality, and environmental degradation in developing countries motivated them to pursue the work they do or influenced their worldview.

Role models, such as family members, mentors, or working models of projects or organizations elsewhere also served as strong influences. Some interviewees credited the formation of altruistic and biospheric values to their childhood; others shared how good models later in life created powerful shifts in their thinking and motivation. In a similar way, Baden \& Parkes (2013) also found how working with social entrepreneurs and/or "responsible" business professionals provides business students with inspirational role models and positive social learning opportunities.

Environmental exposure. Lastly, exposure to the environment in both positive and negative ways also served to influence the initial motivations of sustainability leaders. After observing human impact on the environment (as seen through coastal cleanups, disaster response, etc.), the interviewees concluded that humans could stop the problem too. One conservationist shared:

There was a series of events. The earliest I can remember was joining an underwater clean-up. I joined it because I wanted to escape an exam. The teacher gave us an option to take an exam or volunteer in a clean-up, and I 
was like, well, you know, it wasn't a very hard choice to make. And it was one of those ICC [international coastal clean-up] things that you know, I never really was interested in. So, I was in third year college then, and when I picked up all this trash underwater, it was really an awakening that [expletive], there's so much trash in the ocean already.

Experiences like this could activate biospheric values, whether or not these were already explicitly held (Steg et al., 2013), or provide an awareness of consequences that was difficult to ignore. Such experiences have the potential of leaving the individual with strong negative feelings that they can only get rid of by doing something (Dovidio \& Penner, 2001).

On the positive side, exposure to the natural environment served to enhance an intangible and spiritual connectedness with nature. As some interviewees expressed:

All of this is God's creation and we are called to be stewards of God's creation.

I believe this now, that sustainability is also spiritual. It's about looking deeper into your purpose as a being, as a living being on this planet. How are we participating in this ecosystem? And I think when Buddha became enlightened ... he basically understood the interconnectivity of everything in this universe, in this earth. He woke up to the truth of interdependence, and I mention this because, now this is something that I really believe is in the core of the work that I do.

Three interviewees, all male, cited this specifically; whether or not this is related to traditional gender stereotypes of boys being allowed more time outdoors while girls spent more time indoors could be an area for further inquiry. Nevertheless, it was less surprising that those who expressed connectedness to nature were in the fields of conservation, ecotourism, or environmental policy. It is worth noting, however, that it was a connection with people, or seeing the world through an Aeta (an indigenous people in the Philippines) worldview of kainumayan (holistic well-being, comfort) and kasaganahan (abundance in balance, prosperity), that helped shape one climate activist's ecological worldview. This can be related to the lawyer who shared about going into environmental law after seeing the plight of indigenous peoples.

The interviewees' exposure to both the beauty and destruction of nature followed by reflection thus helped propel them toward sustainability. Indeed, moments for reflection were critical for them to gain insight from their experiences and further develop their ecological worldview (Schein, 2015; Steg et al., 2013). 


\section{Sustaining Motivation}

Positive psychological factors and the desire to pursue what is personally fulfilling to them or avoid what may cause them personal detriment continue to underlie the interviewees' motivations. However, what constitutes fulfilment and detriment may have changed since the time they started and after having devoted more time to their work. These beliefs would have evolved through enhanced self-awareness, social relationships, and connectedness to nature. A long-term vision, therefore, of social and environmental transformation further reinforces other motivations, creating a positive cycle that helps one overcome barriers and challenges. Six main clusters were identified for sustaining motivations, namely, positive psychological factors, self-awareness and self-interest, social relationships, connectedness to nature, growing opportunities in sustainability, and social and environmental transformation.

Positive psychological factors. These factors continued to give interviewees belief in their personal capacity to effect change, find ways forward, and envision positive future outcomes. Some spoke about their optimism, or their stubbornness or willingness to go against the odds, even at the risk of failure. One conservationist shared:

\footnotetext{
Knowing that I can make it happen, I need to make it happen. Like I can't just sit back and not do it, you know?... And I remember reading Big Magic, where Elizabeth Gilbert wrote that you know you love what you do when failure or success doesn't matter. Because people always say, what would you do if you weren't afraid, right? But she flips the question and asks: what would you do if you knew that you would fail still? And I had an epiphany ... whether I fail or succeed in the campaigns that I do, this is still what I'm called to do, you know? I'm not religious, but I feel like this is my purpose.
}

Their history of success and their potential for success in the work they have yet to do gave them a greater sense of confidence or self-efficacy and a willingness to take risks. Indeed, the conservationist above exhibited an internalization (Ryan \& Deci, 2000) of motivation, with work integrated with self-identity and purpose.

Interviewees also had feelings of confidence, hope, and optimism because they also saw the value in starting small, if only to just get started. One respondent talked about how some people get so daunted by the complexity of the problem that they choose not to start at all: 
I also realized that there is a lot of self-flagellation happening nowadays, with people saying, "Oh, the small initiatives are fine, but they're not enough to save the world." I agree. But where do you even begin? And that kind of thinking is dangerous because it pushes people back, and that doesn't really help.

As Walumbwa et al. (2008) describe hope, it serves to create willpower and waypower by setting sub-goals that give one a sense of progress or forward movement. One interviewee celebrates milestones along the way, validating their efficacy and increased feelings of hope:

Small victories matter, so that also gives me hope.... And wow, I drafted this law and now I'm implementing it. When you see that whole range of your impact, you have to be hopeful.

For one urban planner, work entails long periods of planning and approval, and is subject to long, bureaucratic processes. To cope, this interviewee engages in short-term activities to gain a sense of accomplishment while pursuing other longterm projects:

I would also write articles, or give talks or do other things, because at least it feels like there's something you've finished? Right? Because there's so many things I've started but have been unable to finish in these 11 years, like so many. Or you finish the report, but you never do the project. Or you get the first phase, but you never get the continuation, you know? And it would be nice to finish something completely from $A$ to $Z$. For a sense of accomplishment personally, that would be incredible.

Indeed, while acknowledging the long-term nature of sustainability work, this interviewee shares that short-term wins provide the motivation to go on:

We may not achieve the objective right away, but we also see ways that our efforts have made a difference somehow.... In advocacy, l've also learned that we win in inches. We barely win in miles. So when we see that crack of light, that's already okay, until we see the next level.

The interviewees' resilience, discipline, and determination to get back up in the face of failure, treat mistakes as learning opportunities, and see obstacles as greater fuel for creative problem-solving added to their resolve to continue doing their work. As one respondent said,

There are days when you really just have to put one foot in front of the other, and fortunately, what keeps me going is that there are deadlines to meet, because I got a grant, or because I got hired to do something, there are 
deliverables that I need to work on. And that's when passion becomes irrelevant and when discipline becomes more important. In fact, discipline's probably the most important.

Self-awareness and self-interest. As with initial motivation, respondents continued finding happiness and fulfillment through intrinsic rewards such as joy in the work itself and feelings of accomplishment as well as through extrinsic rewards such as creating a model for others to follow and getting validation from others for their work. Two interviewees share below:

The rewarding part for me is when I see other people either repeating or referencing your ideas or stuff that you've worked on, so that you know at least that it's disseminating and inspiring other people.

Sometimes I don't even understand the impact of our work, like, sometimes someone will come up to me and say, "I started this organization in school because I went to one of your talks," or "I wrote a letter to my government about this, and now my government is doing this...." As long as I know that I'm being effective, as long as I'm growing personally and professionally, then I think I'm going to stay in this field.

The desire to avoid negative feelings or consequences also triggered the interviewees' sense of moral obligation that underpins the recognition of their environmental impact as an individual or as a business. This compelled them to continue pursuing sustainability and be consistent in finding more ways to either reduce the harm or increase the good they bring to other people (e.g., by providing equal opportunities) or the environment (e.g., by minimizing their waste). One entrepreneur spoke about their dilemma:

I have manufacturer's guilt, because I'm seeing we have all these good products, which is really what it was about in the beginning. Because even in the beginning when we were choosing the bottles, we were choosing polymers that we knew were highly recyclable-PDPE, HDPE, all of those things were high value.... Because ten years ago, I was naïve enough to think that all of that was being recovered from the market anyway, because they were high value. But ten years down the line, I realized that's not enough. I can't just kind of justify it because, it's okay because all the bottle recyclers will pick it up anyway, and it will be recycled and all of that. Especially after being faced with all the data that's saying only $2 \%$ of all the waste is recycled, and most of it is still sitting in dumpsites, landfills.

It was in the interviewees' interest to live in alignment with their values to avoid the cognitive dissonance if they did otherwise. 
While financial security was not an initial motivator for the interviewees, it was clearly something necessary for most of them to continue on in the pursuit of sustainability.

\begin{abstract}
When people tell me stuff like, "Oh, you're doing such a noble job" or like "You're such a hero," it's gross because the truth is one, I love what I do, obviously, and two, I get paid to do it. If I'm not getting paid to do this work, I wouldn't be in this field. So of course, I built a career out of it, or I'm building a career out of it.

We put everything into this company. It wasn't just that we were do-gooders, but it also meant that it was our survival, so I have a family to support, this needs to work, we need to pay the bills.
\end{abstract}

To continue their work, it was necessary for sustainability leaders to secure funding, either through a regular-paying job or consultancy, or through acquiring grants or greater sales.

Perpetual self-reflection involves the interviewees' need for idle time to ponder on what success, happiness, and fulfillment mean to them. This space for reflection allows them to think about what is valuable to them, and if they have been living in congruence with their values and strengths, while also ensuring their own needs. This can also be related to the Japanese concept of ikigai or "reason for being" which involves achieving a life wherein one finds balance and harmony at the intersection of what one loves, what one is good at, what the world needs, and what one can get paid for (García \& Miralles, 2017).

Finally, it seemed as if the time interviewees put into their work allowed them to internalize their motivation as well as identify more reasons to stay committed and on course, as with the sustainability director who has a "daily reckoning" to recommit themselves to their values and goals:

\footnotetext{
At some point, I had to make a decision whether I would want to move forward with it or not. And I kept saying yes, and I kept saying yes, and I kept saying yes, and this is not just about [my organization], this is also about the company I decided to keep, the way we raised our children, the way we worked at our marriage, the way we worked on our projects.
}

Through reflection and internalization, interviewees identified themselves more with the work they do, the values they hold, and the goals they are working toward. Sustainability leadership is a conscious, self-determined choice they live out day by day. 
Social relationships. One particular social relationship that motivates the interviewees' is their relationship with beneficiaries, whether it be through livelihood creation, defense of human rights, building community platforms, etc. As a result of their work, they saw how people had shifts in perspectives on how they valued the environment and themselves, which echoes the goals of transformational leaders (Bass \& Avolio, 1994). One entrepreneur shared:

I look at our employees: we have 600 people; they have families to support. So if I give up, then I'm also destroying the dreams of 600 people (laughs). That's a lot of pressure!... And for me, it's really the transformation that I see ... there's a shift in how they see themselves, and because they transform how they see themselves, they're able to accomplish more, they're able to dream about the things that are important ... they transform their own dreams.

A supportive team, colleagues, or company culture also helped make interviewees feel less fearful of failure and, more than that, held them more accountable to continuing the work.

I've been very, very, very fortunate that despite the numerous change[s] of hands, the people who have owned the company over the years have exhibited sincere and deep commitment to the environment and to the communities around us.... That also provides for a sense of community that keeps us grounded and when you're in that circle, you can get tired but you really cannot quit.

Apart from their own team or direct work colleagues, having a collaborative community also served to strengthen sustainability leaders' motivation and resolve to continue. Parkin (2010) and Schein (2015) both speak of how sustainability leaders are systems thinkers and "collaborators-in-chief."

If you work in sustainability, it's by nature, [it] cannot be a work by an individual, it has to be work by a community. That gives me joy, to be able to work with a whole range of people all over the world.... So that's also one of the things that gives you hope, right?

Aligned with this, practitioners in sustainability have a relatively higher degree of openness and transparency than those from other fields due to their access to a "safe space" to air their worries, concerns, dreams, and goals.

It's just so important to have people who will empathize with you in the language that you speak in this field. Because we're all just going through the same thing, so it's so important to have that kind of support, to help keep you from burning out and feeling like you're alone, which is like one of the worst feelings ever. 
This gives fellow practitioners a greater sense of being part of a bigger movement, especially when they see the breadth of potential collaborators across sectors, borders, and generations.

Lastly, future generations also play a significant role for many interviewees. One respondent expressed a moral duty to their children to pursue their cause. Acknowledging, moreover, that the work of sustainability is not something that can be fully achieved in their lifetime makes it all the more important that future generations take up the mantle and continue the work that the respondents started. Some cited how Greta Thunberg and the youth strikes for climate served as powerful inspirations for them to keep going. Seeing the youth find careers in sustainable development also gave them hope:

I can see the renewal, so even when it's difficult and we're defeated, I have someone beside me who will take this fight up.... That's the one that gives me hope.... But you know, there's never any end to what you have to do.... And I see replenishment in all the issues that I care about, whether it's locally or nationally or internationally, and that's big. To see that, you know you'll never be defeated.

Connectedness to nature. The spiritual connection with nature continues to play an important role because it makes sustainability more than a profession; instead, it becomes a calling to a higher purpose that is integrated with one's core being. This makes one conservationist more resilient in the face of challenges in their field:

To be honest, if I am a scientist and a development worker only without any spiritual source of strength, I don't think I'll ever be happy.... If I'm in that world only because of the profession or only because it's a job, I don't think I'll keep it.... I need to connect to that spiritual purpose.

Growing opportunities in sustainability. Increasing public interest, funding, and support also served to encourage interviewees to pursue this path. Since David Attenborough's Blue Planet II documentary in 2017 as well as Greta Thunberg's and Extinction Rebellion's mobilization efforts in 2018 and 2019 (Laville, Noor, $\&$ Walker, 2019), there has been greater awareness of and social movement on the issues surrounding plastic pollution and climate change. As one interviewee shared,

There's so much more attention on plastic. Money is being thrown into recycling and plastics, and like, I have to ride this wave while it's here, because in a few years, who knows, no one will care about the ocean. Because there are different trends in the environmental movement. So for now, I think I have to just walk into these opportunities that have opened up that weren't there a few years ago. 
Indeed, it is worth noting that while going against the status quo was expected of early sustainability leaders, support for sustainability is increasingly becoming a social norm that drives other leaders to emerge as well.

Social and environmental transformation. Most interviewees shared a larger overarching motivation for changing mindsets and behavior, regenerating the environment, challenging the status quo, "hacking the system," creating working models, and blazing the trail for the next generation of leaders. Their work is a lifelong mission the results of which they may not see in their lifetime, although that would not stop them. One interviewee expressed this powerfully:

\footnotetext{
Campaigning or advocacy work, sometimes you don't reach your objective. But along the way, you're contributing to something, whether you're changing the system, you're inspiring other people to do it, or yeah, you're planting seeds that will one day bloom into something, and maybe you won't even be alive to see it, you know? But there is value in the pursuit of something even if you don't win. And I always try to think about that when I get frustrated with my work.
}

Possessing positive psychological factors, having acute self-awareness, finding validation and feedback from various social groups, enhancing their ecological worldview, learning about new opportunities, and keeping their goals in mind-all these contributed to sustaining the initial motivation of the interviewees.

\section{A FRAMEWORK FOR SUSTAINABILITY LEADER MOTIVATION}

Based on the results of the study, the initial and sustained motivation of sustainability leaders are a combination of positive psychological factors, life experiences, validation or feedback, and long-term goal orientation.

Positive psychological factors can be related back to authentic leadership and to the predisposition of sustainability leaders for confidence, hope, optimism, and resilience (Northouse, 2016; Walumbwa, Avolio, Gardner, Wernsing, \& Peterson, 2008). Life experiences or exposure and subsequent reflection as described by the interviewees can also be related to the findings by Rogers (2012), Rimanoczy (2013), and Schein (2015) as well as to the discussion on how critical life events shape authentic leaders by Walumbwa et al. (2008). Validation and feedback from self-reflection, peers, beneficiaries, and the wider public, along with the positive impact that one's work produces, further reinforce motivation (Dovidio et al., 2006). Lastly, the sustainability 
leaders interviewed were guided by a long-term vision of sustainability, one of social and environmental transformation, and of a society that values purpose, mindfulness, compassion, community, and oneness with nature.

The resulting framework as such draws on elements seen in the Value-BeliefNorm Theory (see Figure 1) and theoretical approach to authentic leadership.

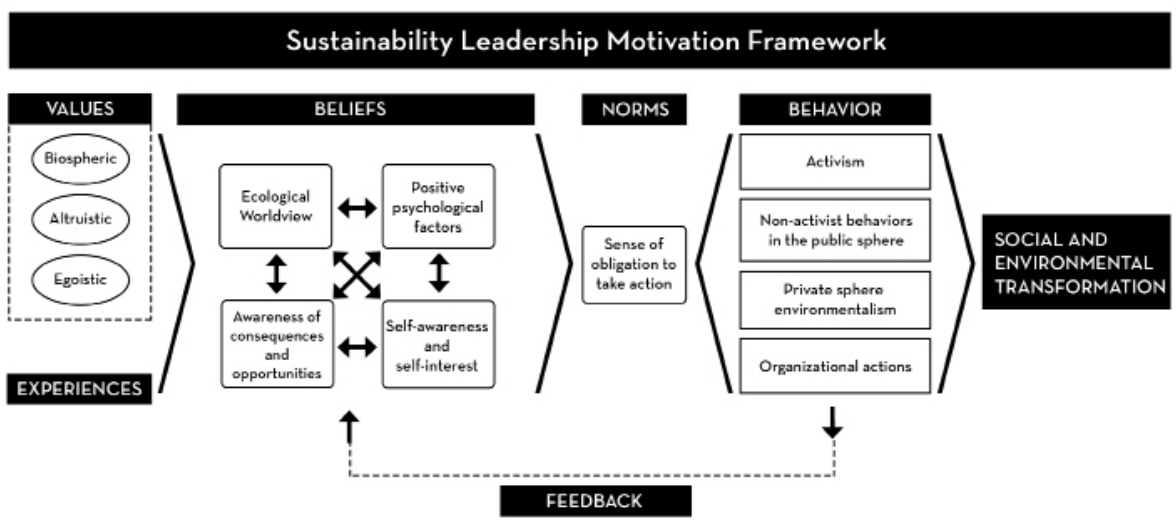

Figure 3: A Framework for Understanding the Motivation of Sustainability Leaders

The VBN, however, does not discuss how sustainable behavior might also be influenced by more positive factors, including an awareness of opportunities and not just of consequences; a sense of personal fulfilment or happiness and not just obligation; and a goal or goals directing the motivation or behavior given that motivation is the process wherein goal-directed behavior is instigated and sustained (Schunk, Pintrich, \& Meece, 2008). It also does not factor a more dynamic interaction of one's beliefs. This provides room to explore how the theory can be built to factor in these components, along with other motivations, beliefs, and attributes of leaders who possess personal norms of moral obligation. The VBN as such is adapted to understanding the motivation of sustainability leaders with the inclusion or modification of the components explained in the following paragraphs.

Experiences. Interviewees consistently reported how experiences, more than just their existing values, would shape or reshape their beliefs, including their awareness of the world around them and their own capabilities, interests, and responsibilities (Rimanoczy, 2013; Rogers, 2012; Schein, 2015). Powerful experiences would serve to create epiphanies while other, more prolonged ones would gradually mold their beliefs over time. 
An awareness of opportunities. For the more entrepreneurial interviewees, finding opportunities such as new business ideas, community networks, partnerships, funding, or grant competitions helped motivate them. More than just an awareness of negative consequences, therefore, were other key motivators such as knowing the areas where they can effect change and the strategies they can use.

Positive psychological factors. Confidence, hope, optimism, and resilience contributed to an empowered mindset that allowed the interviewees to set greater goals, have greater commitment, and work harder to lead others toward sustainability.

Self-awareness and self-interest. More than just an ascription of responsibility (Stern et al., 1999; Stern, 2000), the more congruent or aligned the interviewees felt with their own values, strengths, interests, and goals, the more motivated they were to pursue sustainability leadership (Ryan \& Deci, 2000; García \& Miralles, 2017). For some interviewees, the more they identified with their role or their work as part of who they were, the stronger their commitment to their behaviors and goals. Furthermore, both intrinsic and extrinsic motivators, ranging from joy in the work itself to the need to make money to support one's self and one's family, played a role in shaping their beliefs about the advantages of continuing in their work.

Dynamic interaction of beliefs. The VBN model discusses a linear process to explain sustainable behavior, with each factor leading to the next. However, it does not factor in how self-awareness and positive psychological factors interact with one's ecological worldview or awareness of consequences and opportunities. Indeed, an awareness of opportunities may also result from further introspection on one's values, strengths, and goals. For some interviewees, it took some (or perpetual) selfreflection to understand what they were or were not capable of, and it was not until they realized their strengths and developed greater confidence that they saw more opportunities available to them.

Feedback. This contributed to shaping the interviewees' beliefs about how they work as well as what works and what does not. It was rewarding for them, for example, when they saw beneficiaries being able to send their children to school and whenever they receive gratitude from employees or community members for the work they do. The sense of congruence validated their need for identity and the sense of accomplishment validated their need for creation, participation (Max-Neef, Elizalde, \& Hopenhayn, 1991), and a feeling of relatedness (Ryan \& Deci, 2000). Feedback 
could likewise come in the form of barriers which shaped their learning about how the world works or about the extent of their personal capacity, and which gave them insight on how to proceed better with the work that they do (Bandura, 1997).

Social and environmental transformation. Motivation is said to be goal-directed behavior (Schunk et al., 2008). Hope requires an end goal for it to exist. As such, it is necessary to illustrate what the beliefs and behaviors of sustainability leaders are working toward. The interviewees had a common desire to create change beyond their personal sphere and empower those they influence (e.g., followers, employees, customers, etc.) to effect change in their own way as well. Although they vary in the scale of ambition (to effect organizational, community, national, or global change) and clarity (having specific, detailed, and measurable goals in the next one, five, or ten years), they were ultimately guided by a desire to contribute to changing the world for the better.

\section{CONCLUSION}

What do these findings reveal about developing future sustainability leaders or sustaining the momentum of existing ones? From these results, we can reasonably infer the importance of creating leadership development programs that enhance the positive psychological capacities of individuals, utilize experiential learning, and highlight community-building and connectedness to nature. All this must be done while showing participants how to set their own short- and long-term goals so that they can celebrate milestones or small wins on the way toward a greater goal of social and environmental transformation. This is by no means an easy feat, and yet a necessary one to consider. It will be made possible by employing some or all of the following strategies, whether in the context of corporate sustainability leadership programs or higher education.

\section{Cultivating Hope}

One theme that came out strongly across the interviews and emerging in leadership theories is the development of positive psychological capacities, particularly hope. It is fortunate that hope, while recognized as a trait, is a state that can be developed (Helland \& Winston, 2005; Rego, Sousa, Marques, \& e Cunha, 2014; Luthans \& Youssef, 2004), whether in higher education, corporate learning 
and development, entrepreneurship bootcamps, or other such programs. Students or participants can learn appropriate goal-setting and envision realistic pathways, break down big goals into sub-goals, delegate and empower others, engage in positive self-talk, re-frame and readjust goals when faced with barriers, and have peer support groups or coaching (Luthans \& Youssef, 2004; Rego et al., 2014).

\section{Experiential Learning}

The most critical insights in this study came from the awareness of consequences and opportunities that came through first-hand experience. The Cambridge Institute for Sustainability Leadership (CISL, 2017) also suggests that leadership development programs should integrate placements or immersions for key functions and for all levels within the business, including the board. For these approaches to be truly effective, it is important that clear structures for reflecting upon the experience and applying the learning accordingly be put in place. Making issues more personal for individual leaders helps them to be more committed and empowered to act in favor of sustainability (Arden, 2019; Haney et al., 2018).

Existing sustainability leaders can also benefit from self-reflection and regular feedback mechanisms from others when they actually do the work. By creating space to reflect upon the experience, they can learn what to do to be more effective the next time around. Getting constructive feedback from beneficiaries, team members, partners, and peers is also helpful, and not just in informing them of better actions to take but, when given well, also in serving to strengthen their motivation.

Social support and enabling environments. To sustain motivation, it was important for the interviewees to have a reasonable expectation for success as well as a support system from which they could gain not only technical knowledge but also, and more importantly, a source of emotional strength and empathy (Max-Neef et al., 1991). As such, community or peer learning groups (Leal Filho et al., 2018), getting executive buy-in by involving the board in sustainability leadership programs (Arden, 2019; CISL, 2017), and coaching are measures to integrate in sustainability education and leadership programs. Creating platforms to keep participants connected after the programs, moreover, can also help provide continued support in their journeys and challenges (Leal Filho et al., 2018). 


\section{Suggestions for Future Research}

The relationship between ecological worldviews, positive psychological factors, and the motivation to engage in sustainability leadership can be examined further with bigger samples, and particularly through the use of instruments such as the New Ecological Paradigm (NEP; see Dunlap, van Liere, Mertig, \& Emmet Jones, 2000), Motivation Toward the Environment Scale (MTES; see Pelletier, Tuson, Green-Demers, Noels, \& Beaton, 1998), and Authentic Leadership Questionnaire (ALQ; see Avolio, Walumbwa, \& Weber, 2009; Walumbwa et al., 2008) to provide better information on how these factors contribute to sustainability leadership. An instrument can also be developed to measure sustainability leadership motivation at the beginning and end of sustainability leadership programs to help inform about their effectiveness not only in passing on information to those who attend their classes or workshops but also in inspiring participants to take greater action for sustainability.

\section{REFERENCES}

Arden, Z. 2019. How can we achieve high-impact leadership? The role of experiential learning. Cambridge Institute for Sustainability Leadership. Available at https:// www.cisl.cam.ac.uk/news/blog/how-can-we-achieve-high-impact-leadership.

Avolio, B. J., \& Gardner, W. L. 2005. Authentic leadership development: Getting to the root of positive forms of leadership. The Leadership Quarterly, 16(3): $315-338$.

Avolio, B. J., Walumbwa, F. O., \& Weber, T. J. 2009. Leadership: Current theories, research, and future directions. Annual Review of Psychology, 60: 421-449.

Baden, D., \& Parkes, C. 2013. Experiential learning: Inspiring the business leaders of tomorrow. The Journal of Management Development, 32(3): 295-308.

Bamberg, S., Hunecke, M., \& Blöbaum, A. 2007. Social context, personal norms and the use of public transportation: Two field studies. Journal of Environmental Psychology, 27(3): 190-203. 
Bandura, A. 1977. Social learning theory. Englewood Cliffs, NJ: Prentice Hall.

Bandura, A. 1997. Self-efficacy: The exercise of control. New York: W. H. Freeman and Company.

Bass, B. M., \& Avolio, B. J. (Eds.). 1994. Improving organizational effectiveness through transformational leadership. Thousand Oaks, CA: Sage.

Braun, V., \& Clarke, V. 2006. Using thematic analysis in psychology. Qualitative Research in Psychology, 3(2): 77-101.

Burns, H., Diamond-Vaught, H., \& Bauman, C. 2015. Leadership for sustainability: Theoretical foundations and pedagogical practices that foster change. International Journal of Leadership Studies, 9(1): 131-143.

Chouinard, Y. 2006. Let my people go surfing: The education of a reluctant businessman. New York: Penguin Books.

CISL [University of Cambridge Institute for Sustainability Leadership]. 2017. Building leaders for long-term business performance: Research findings. Cambridge, UK.

Dovidio, J. F., \& Penner, L. A. 2001. Helping and altruism. In G. Fletcher \& M. S. Clark (Eds.), Blackwell handbook of social psychology, vol. 2: Interpersonal processes: 83-103. New York: Springer-Verlag.

Dovidio, J. F., Piliavin, J. A., Schroeder, D. A., \& Penner, L. A. 2006. The social psychology of prosocial behavior. New Jersey: Lawrence Erlbaum Associates, Inc.

Dunlap, R. E., van Liere, K. D., Mertig, A. G., \& Emmet Jones, R. 2000. Measuring endorsement of the new ecological paradigm: A revised NEP scale. Journal of Social Issues, 56(3): 425-442.

García, H., \& Miralles, F. 2017. Ikigai: The Japanese secret to a long and happy life. London: Hutchinson.

Gerber, T. 2017. Becoming Jane. National Geographic, October: 30-51.

Gilbert, N. (Ed.). 2001. Researching social life (2nd ed.). London: Sage Publications Ltd. 
Goleman, D. 2004. Emotional intelligence \& working with emotional intelligence. London: Bloomsbury Publishing Plc.

Goleman, D., Boyatzis, R., \& McKee, A. 2002. The new leaders: Transforming the art of leadership into the science of results. London: Time Warner Books UK.

Graves, L. M., \& Sarkis, J. 2018. The role of employees' leadership perceptions, values, and motivation in employees' proenvironmental behaviors. Journal of Cleaner Production, 196: 576-587.

Haney, A. B., Pope, J., \& Arden, Z. 2018. Making it personal: Developing sustainability leaders in business. Organization \& Environment, 33(2): 155-174.

Helland, M. R., \& Winston, B. E. 2005. Towards a deeper understanding of hope and leadership. Journal of Leadership \& Organizational Studies, 12(2): 42-54.

Hunecke, M., Blöbaum, A., Matthies, E., \& Höger, R. 2001. Responsibility and environment: Ecological norm orientation and external factors in the domain of travel mode choice behavior. Environment and Behavior, 33(6): 830-852.

Laville, S., Noor, P., \& Walker, A. 2019. 'It is our future': Children call time on climate inaction in UK. The Guardian, Feb 15. Available at https://www.theguardian. com/world/2019/feb/15/children-climate-inaction-protests-uk.

Leal Filho, W., Raath, S., Lazzarini, B., Vargas, V. R., de Souza, L., Anholon, R., Quelhas, O. L. G., Haddad, R., Klavins, M., \& Orlovic, L. V. 2018. The role of transformation in learning and education for sustainability. Journal of Cleaner Production, 199: 286-295.

Luthans, F., \& Youssef, C. M. 2004. Human, social, and now positive psychological capital management: Investing in people for competitive advantage. Organizational Dynamics, 33(2): 143-160.

Max-Neef, M., Elizalde, A., \& Hopenhayn, M. 1991. Human scale development: Conception, application and further reflections. New York: The Apex Press.

Miles, M. B., Huberman, A. M., \& Saldaña, J. 2014. Qualitative data analysis: A methods sourcebook (3rd ed.). Thousand Oaks, CA: Sage Publications, Inc. 
Northouse, P. 2016. Leadership: Theory and practice (7th ed.). Thousand Oaks, CA: Sage.

Parkin, S. 2010. The positive deviant: Sustainability leadership in a perverse world. London: Earthscan.

Pelletier, L. G., Tuson, K. M., Green-Demers, I., Noels, K., \& Beaton, A. M. 1998. Why are you doing things for the environment? The motivation toward the environment scale (MTES). Journal of Applied Social Psychology, 28(5): 437-468.

Pless, N. M. 2007. Understanding responsible leadership: Role identity and motivational drivers. Journal of Business Ethics, 74(4): 437-456.

Rego, A., Sousa, F., Marques, C., \& e Cunha, M. P. 2014. Hope and positive affect mediating the authentic leadership and creativity relationship. Journal of Business Research, 67(2): 200-210.

Rimanoczy, I. 2013. Big bang being: Developing the sustainability mindset. Sheffield, UK: Greenleaf Publishing.

Robertson, J. L., \& Barling, J. 2013. Greening organizations through leaders' influence on employees' pro-environmental behaviors. Journal of Organizational Behavior, 34(2): 176-194.

Robertson, J. L., \& Barling, J. 2017. Contrasting the nature and effects of environmentally specific and general transformational leadership. Leadership \& Organization Development Journal, 38(1): 22-41.

Rogers, K. S. 2012. Exploring our ecological selves within learning organizations. The Learning Organization, 19(1): 28-37.

Ryan, R. M., \& Deci, E. L. 2000. Intrinsic and extrinsic motivations: Classic definitions and new directions. Contemporary Educational Psychology, 25(1): 54-67.

Schein, S. 2015. A new psychology for sustainability leadership: The hidden power of ecological worldviews. Sheffield, UK: Greenleaf Publishing. 
Schunk, D. H., Pintrich, P. R., \& Meece, J. L. 2008. Motivation in education: Theory, research, and applications (3rd ed.). Upper Saddle River, NJ: Pearson Merrill Prentice Hall.

Schwartz, S. H. 1992. Universals in the content and structure of values: Theoretical advances and empirical tests in 20 countries. In M. Zanna (Ed.), Advances in experimental social psychology, vol. 25: 1-65. Orlando, FL: Academic Press.

Schwartz, S. H. 1994. Are there universal aspects in the structure and contents of human values? Journal of Social Issues, 50(4): 19-45.

Shamir, B., \& Eilam, G. 2005. "What's your story?" A life-stories approach to authentic leadership development. The Leadership Quarterly, 16(3): 395-417.

Silverman, D. 2014. Interpreting qualitative data (5th ed.). Ashford, UK: Sage Publications, Inc.

Steg, L., van den Berg, A., \& de Groot, J. 2013. Environmental psychology: An introduction. Chichester, UK: Blackwell Publishing.

Stern, P. C. 2000. Toward a coherent theory of environmentally significant behavior. Journal of Social Issues, 56(3): 407-424.

Stern, P. C., Dietz, T., Abel, T., Guagnano, G. A., \& Kalof, L. 1999. A value-belief-norm theory of support for social movements: The case of environmentalism. Human Ecology Review, 6(2): 81-97.

Swain, J. 2018. A hybrid approach to thematic analysis in qualitative research: Using a practical example. London: Sage Publications.

Venhoeven, L. A., Bolderdijk, J. W., \& Steg, L. 2016. Why acting environmentallyfriendly feels good: Exploring the role of self-image. Frontiers in Psychology, 7: 1846.

Walumbwa, F. O., Avolio, B. J., Gardner, W. L., Wernsing, T. S., \& Peterson, S. J. 2008. Authentic leadership: Development and validation of a theory-based measure. Journal of Management, 34(1): 89-126. 
Jennifer Licad Horn sows seeds and holds space for reflections and conversations on human and environmental regeneration. As founder of Muni, she grows a community for mindful living through events and content, like the Muni on This podcast, which features sustainability leaders and advocates sharing stories about the challenges and possibilities in creating a more mindful and livable world. Jen is also a sustainability lecturer, or learning facilitator, at the Department of Leadership \& Strategy of the John Gokongwei School of Management, Ateneo de Manila University. She completed her MSc in Sustainable Development with distinction from the University of Surrey's Center for Environment \& Sustainability in the U.K. under the prestigious Chevening scholarship. She also received her AB Psychology degree from De La Salle University with honorable mention and will complete her International Coaching Federation (ICF) accredited core training for professional coaching with Coach Masters Academy in February 2021.

After studying economics and business administration in Marburg, Germany, Walter Wehrmeyer also did an undergraduate degree in Development Studies, followed by a $\mathrm{PhD}$ in Industrial Environmental Management at the University of Kent. He joined the Centre for Environment and Sustainability (CES) initially as the BG Surrey Scholar in Risk Communication, focusing on engagement strategies toward contaminated land remediation and management. After the successful completion of this project, he worked as Senior Lecturer and Reader in Environmental Business Management, looking as of late at CSR and sustainability beyond "environment." 